\title{
Ideologie dżucze jako element silnie oddziałujący na społeczeństwo w Korei Północnej
}

\section{Wprowadzenie}

Koreańska Republika Ludowo-Demokratyczna stanowi relikt przeszłości świata dwubiegunowego. Współcześnie jest to jedyne państwo totalitarne na świecie, którego ideologia dżucze pełni istotną funkcję w sferze polityki, gospodarki, bezpieczeństwa i w sferze społeczno-kulturowej. Korea Północna z ideologią dżucze na czele wyraża swoistą harmonię, gdzie mimo wzmianek o tragicznej sytuacji, dzięki którym spekuluje się o upadku reżimu, jeszcze długo sytuacja nie ulegnie zmianie. Ideologia Korei Północnej stawia na niezależność polityczną, gospodarczą i militarną państwa, jednym słowem - dżucze to samowystarczalność.

Koncepcja Kim Ir Sena jest również silnie związana z północnokoreańskim społeczeństwem. Jak podkreśla propaganda komunistycznego reżimu, doktrynalny kontekst $d \dot{z} u c z e$ zawiera uniwersalne zasady oraz wartości, bez których podstawy i rozwój społeczeństwa Korei Północnej stają się niemożliwe do osiągnięcia, wręcz skazane są na całkowite niepowodzenie. W doktrynie dżucze specyficznego znaczenia nabierają fundamentalne wartości i zasady, które mają istotny wpływ na zachowania i podstawy jednostek i grup społecznych

* Magister, doktorant, Uniwersytet Łódzki, Wydział Studiów Międzynarodowych i Politologicznych, Zakład Azji Wschodniej. 
oraz na przejawy wszelkich form aktywności obywatelskiej. Należy do nich zakwalifikować odpowiedzialność, pomocniczość, partnerstwo, sprawiedliwość społeczną, solidarność, suwerenność, czy tożsamość narodową.

\section{Ideologia dżucze i jej geneza}

Podejmując tematykę społeczeństwa w Korei Północnej, należy najpierw omówić genezę pojęcia oraz wyjaśnić, czym w zasadzie jest ideologia dżucze. Wyjaśnienie zasad tejże doktryny jest niezbędne, aby w pełni zrozumieć, jak istotną rolę odgrywa w analizowanym społeczeństwie. Kimirsenowska koncepcja stanowi bowiem fundament systemu społecznego w północnej części Półwyspu Koreańskiego.

Pierwsza udokumentowana wzmianka o ḋucze pojawia się w 1955 roku, podczas przemówienia Kim Ir Sena pt. O wykorzenieniu dogmatyzmu i formalizmu i ustanowieniu Dżucze w pracy ideologicznej ${ }^{1}$. Andrew Scobell zauważa, że wielu badaczy zajmujących się Koreą Północną uzasadnia niezwykłość systemu politycznego tego kraju. Reżim północnokoreański stanowi organizm posiadający dwie niezbędne i najważniejsze cechy. Po pierwsze, rządy sprawuje rodzina Kimów, działająca na wzór zorganizowanej grupy przestępczej, po drugie, system ten to korporacyjny organizm² ${ }^{2}$

Waldemar J. Dziak zaznacza, że Korea Północna posiada wysoko scentralizowany i zmilitaryzowany biurokratyczny reżim, gdzie wszystko jest związane z potężnym wodzem. Północnokoreańska propaganda lansuje tezę, że wódz równa się system, jest tożsamy $z$ ideologią i przede wszystkim stoi na czele społeczeństwa. W.J. Dziak akcentuje, że bez umiłowanego przywódcy, zarówno $d \dot{z} u c z e$, jak i społeczeństwo nie miałyby szansy istnienia i przetrwania. Nawet jeżeli to istnienie charakteryzowałoby się brakiem poczucia bezpieczeństwa, stałoby się niekompletne, nie stanowiłoby harmonii. Logicznie wnioskując, to wszystko zapewnia istnienie nieomylnego lidera ${ }^{3}$.

Erik Cornell zwraca uwagę, że $d \dot{z} u c z e$ to potężny i budzący grozę system, który kładzie ogromny nacisk na państwo i społeczeństwo - żądając ciągłej aktywności i mobilizacji obywateli ${ }^{4}$. Nie sposób w związku z tym nie zauważyć, że utrzymywanie tak wysokiej ideologicznej indoktrynacji, wiecznie czujnego

\footnotetext{
1 W.J. Dziak, Korea Północna. U źródeł rodzinnej sukcesji, Warszawa 2009, s. 113-114.

2 A. Scobell, Kim Jong Il and North Korea: The Leader and the System, Morrisville 2013, s. $1-2$.

3 W.J. Dziak, op. cit., s. 153-154.

4 E. Cornell, North Korea under Communism: Report of an Envoy to Paradise, London 2002, s. 69.
} 
aparatu przymusu oraz organizacji dużej obrony narodowej wśród społeczeństwa należy do wysokich i ostatecznie może wpływać destrukcyjnie na system, ideologię i formę społeczeństwa.

Mając powyższe na względzie, należy wyjaśnić, czym jest dżucze? Samo słowo oznacza "samowystarczalność" i znane jest Koreańczykom od bardzo dawna, lecz podczas japońskiej okupacji Korei wykształcił się specyficzny sens tego słowa, mianowicie zaczęto określać nim patriotę walczącego za ojczyznę, o wolność, kierującego się wiarą we własne siły. Kim Ir Sen zmodyfikował to pojęcie i posłużył się nim do rozwinięcia trwałego procesu politycznego, który doprowadził Koreę Północną do pełnej niezawisłości, suwerenności, niezależności i desatelizacji na arenie międzynarodowej. Innymi słowy, Wielki Wódz przekształcił to, co kiedyś oznaczało zmaganie się o własny status w społeczeństwie i patriotyzm na wysiłki zmierzające do osiągnięć całego północnokoreańskiego narodu ${ }^{5}$. Formułując doktrynę polityczną, jak wskazuje W.J. Dziak, Kim Ir Sen postawił na wszelako rozumianą samodzielność. Według twórcy koreańskiego systemu totalitarnego, dżucze opiera się na następujących czterech nadrzędnych zasadach:

- samodzielność w ideologii - odrzucanie obcych wzorców ideologicznych nie uwzględniających specyfiki, możliwości, tradycji, przeszłości historycznej, aspiracji i dążeń mieszkańców Korei Północnej;

- niezależność w polityce - nieuleganie naciskom politycznym i ingerencjom z zewnątrz, które prowadzą do stopniowej utraty suwerenności, ale prowadzenie własnej niezależnej polityki w kontaktach międzynarodowych;

- samodzielność w gospodarce - nieuzależnianie się gospodarcze od innych państw i organizacji, bo prowadzi to do utraty suwerenności politycznej, ale twórcze rozwijanie gospodarczych zdolności własnego narodu przy równoprawnej wymianie handlowej ze światem;

- samodzielna obrona kraju - obrony nie można powierzać innym, gdyż prowadzi to do utraty własnej suwerenności, ale trzeba posiadać własny, samodzielny przemysł obronny oparty na własnej myśli technicznej, surowcach i mocach wytwórczych oraz ogólnonarodowy system obrony ${ }^{6}$.

Christopher Hale zwraca uwagę, że na przestrzeni lat ideologia dżucze wykrystalizowała się w uniwersalny, spójny i zwarty system, dostarczający odpowiedzi nie tylko na wszystkie problemy współczesnego świata, ale także na wszelkie zagadnienia wyłaniające się w toku budownictwa komunistycznego, takie jak trudna sytuacja ekonomiczna w kraju czy kwestia roli, jaką człowiek,

W.J. Dziak, op. cit., s. 156-157.

6 Ibidem, s. 115-118. 
masy ludowe, naród, społeczeństwo odgrywają w komunistycznej rewolucji ${ }^{7}$. W nawiązaniu do powyższego, nasuwa się wniosek, że doktrynalny światopogląd formułuje naukowe filary do uzasadnienia poprawnego i właściwego rozumienia północnokoreańskiego społeczeństwa.

\section{Doktrynalno-ideologiczne podstawy społeczeństwa w Korei Północnej}

Punktem wyjścia do wszelkich rozważań na temat społeczeństwa w Korei Północnej jest dżuczowska wizja nowego człowieka, ponieważ od tej konkretnej idei wszystko się zaczęło. W dżucze człowiek znajduje się w centrum uwagi, jest władcą świata, jako jedyny panuje nad swoim losem i przede wszystkim jest istotą społeczną. Społeczność zaś posiada świadomość, zdolność do twórczego działania i samodzielność. Jednakże, co podkreśla kimirsenowska ideologia, te trzy komponenty nie są wrodzone, ale kształtują się w procesie rozwoju społeczno-historycznego. Samodzielność to naturalna cecha człowieka, o ile ów człowiek jest istotą społeczną, która działa, walczy, zrywa poddaństwo, przeobraża przyrodę. Bez samodzielności człowiek nie odróżnia się od zwierzęcia, w związku z tym nie ma zdolności do twórczego działania - głównie w swoim interesie i według swych potrzeb nie przeobraża przyrody i społeczeństwa w sposób celowy. Taki człowiek nie jest świadomy, a tylko świadomość jest gwarantem samodzielności i twórczej zdolności człowieka jako istoty społecznej.

Należy pamiętać, że w północnokoreańskiej ideologii to świadomość kształtuje byt, a o wszystkim przesądza wizja człowieka. W związku z tym o rozwoju społeczeństwa decydują ludzie propagujący postępowe idee i przede wszystkim osoby przepełnione ideologią.

Człowiek, jak przekonuje dżucze, będąc istotą świadomą, społeczną, samodzielną i twórczą może zaistnieć tylko wtedy, kiedy zacznie żyć życiem społeczno-politycznym. Koncepcja Wielkiego Wodza propaguje ideę, że człowiek posiada dwa życia. Pierwsze związane jest z biologicznymi potrzebami organizmu, ma swój początek i koniec, a kierowanie się jedynie nimi przemienia człowieka w zwierzę. Natomiast drugie życie stanowi przepustkę do nieśmiertelności, to życie społeczno-polityczne. Człowiek żyjący życiem społeczno-politycznym stanowi część społecznego kolektywu i prowadzi swoją działalność na rzecz życia społeczno-politycznego państwa i w bezpośrednim związku z nim. A więc człowiek dżucze jest wolny, świadomy, kreatywny i samodzielny, ale żyjąc poza życiem społeczno-politycznym, nie posiada żadnych wartości. Jak przekonuje

C. Hale, Multifunctional Juche: A Study of the Changing Dynamic between Juche and the State Constitution in North Korea, „Korean Journal” 2002, no. 3, s. 283-308. 
sam Kim Jong Il, dopiero człowiek zjednoczony z kolektywem, z partią, która zapewnia życie społeczno-polityczne, i przede wszystkim $\mathrm{z}$ wodzem staje się istotą wartościową. To kolektywizm sprawia, że człowiek jest w stanie dokonać czegoś użytecznego dla społeczeństwa i pozostawić coś w imię wiecznie żyjącego kolektywu ${ }^{8}$. Wnioskując z powyższego, człowiek może umrzeć, ale kończy się tylko jego życie biologiczne, ponieważ jeżeli kierował się ideami społeczno-politycznymi, zapewnił sobie nieśmiertelność.

Dla lepszego zrozumienia społeczeństwa w Korei Północnej należy omówić kwestię kolektywu. Otóż jest on równoznaczny z masą ludową i obejmuje cały północnokoreański naród. Człowiek rezygnuje z indywidualnych potrzeb na rzecz potrzeb kolektywu, uznaje więc priorytet państwa i społeczeństwa, ponieważ kolektyw jako masa ludowa stanowi siłę do wszelkich zmian. W Korei Północnej kolektywizm objął swoim zasięgiem wszystkie dziedziny życia społecznego - system edukacji, rodzinę, partię czy środowisko pracownicze. A jego rola jest niezwykle ważna, gdyż prawdziwe życie dla świadomego człowieka to życie społeczno-polityczne, realizowane wyłącznie w ramach kolektywu. Jak słusznie zauważa W.J. Dziak, od momentu proklamowania Koreańskiej Republiki Ludowo-Demokratycznej Kim Ir Sen nie tylko dążył do zbudowania nowego państwa, ale pragnął ustanowić nowy ład polityczny, który opierałby się na zasadach powszechnego kolektywizmu9. Łatwo wywnioskować, że w Korei Północnej wszystko jest kolektywem. Każdy aspekt życia opiera się na kolektywizmie, występuje on $\mathrm{w}$ szkole, $\mathrm{w}$ pracy, $\mathrm{w}$ domu, $\mathrm{w}$ wyborze form wypoczynku.

Wedle Kim Ir Sena, powyższa kategoryzacja jednostki w kolektywie winna przyczynić się do powstania kolektywnej odpowiedzialności, czujności i strachu. Przy czym miało zrodzić się kolektywne sumienie, które powinno ostatecznie unicestwić wszelkie zalążki lub pozostałości indywidualizmu ${ }^{10}$.

Nasuwa się tutaj jeden niezaprzeczalny wniosek, mianowicie człowiek $d \dot{z} u-$ cze to tania siła robocza, jego najważniejszym zadaniem, o którym ciągle musi pamiętać, jest praca bez ograniczeń, ponad siły, bez zapłaty, a nawet wbrew swej woli. Zdaniem W.J. Dziaka, człowiek dizucze jest jedynie politycznym tworem z przypisaną mu rolą i obowiązkami, to ideologiczny element większej całości, nigdy jednostka, konsument, czy indywidualny byt ${ }^{11}$. Człowiek poddany procesowi północnokoreańskiej indoktrynacji jest na wskroś fanatyczny, agresywny, apodyktyczny, brutalny i nie myśli. Całkowicie podporządkowuje się woli

\footnotetext{
8 Kim Jong Il, Szkalowanie socjalizmu jest niedopuszczalne, Warszawa 1994, s. 23-28.

9 W.J. Dziak, op. cit., s. 142.

10 Kim Ir Sen, O rewolucjonizowaniu całego społeczeństwa i przeobrażaniu jego na obraz klasy robotniczej, Phenian 1982, s. 33, 58, 91.

11 W.J. Dziak, op. cit., s. 140-141.
} 
wodza, partii, w każdej sytuacji działa zgodnie z zaprogramowanymi ideami, bez żadnego sprzeciwu wykonuje polecenia, jest po prostu polityczno-ludzką maszyną ${ }^{12}$. Jak zaznacza Bradley K. Martin, niestosownością i uproszczeniem byłoby stwierdzenie, że permanentnym celem indoktrynacji jest wychowanie człowieka na zaprogramowaną maszynę. Indoktrynacja zakłada wpojenie zasad bezinteresowności ${ }^{13}$.

Ważny z punktu widzenia omawianej problematyki jest pogląd związany ze sposobem rozumienia roli masy ludowej. Otóż według ideologii dżucze, masy ludowe stanowią siłę napędową rewolucji, to wyłączny twórca historii, to siła zdolna do przeobrażeń natury i społeczeństwa zgodnie z własnymi potrzebami oraz interesami. Jak twierdził Kim Jong Il, masy ludowe posiadają siłę i rozum, nie istnieje dla nich żadna bariera, a tylko masy dążące do samodzielności zdolne są odróżnić „słuszną drogę” od złej czy „właściwy pogląd”14.

Kimirsenowska ideologia zakłada wizję, w myśl której istotnym kryterium określającym przynależność do mas ludowych jest ideologia człowieka, a nie jego społeczno-klasowe pochodzenie ${ }^{15}$. Oznacza to jedno, członkiem mas ludowych może zostać inteligent, żołnierz czy chłop. Może nim być każdy, ale pod warunkiem, że za jedyną i właściwą drogę uzna służbę Wielkiemu Wodzowi. Tak więc, partycypantem mas ludowych może zostać każdy bez względu na status społeczny, pochodzenie i kolor skóry, może nim być Koreańczyk z Północy, a nawet kapitalista, wystarczy jedynie spełnić kryterium miłości do wodza i wspierać komunistyczno-koreańską rewolucję.

Nietrudno wywnioskować, że w kolektywizmie tkwi fanatyzm. W związku z tym, wyrażony indywidualnie bądź kolektywnie fanatyzm stanowi wielką siłę, oczywiście tylko i wyłącznie wtedy, kiedy zostanie ujarzmiony poprzez polityczną dyscyplinę, wolę Drogiego Przywódcy i zostanie poddany ideologicznej indoktrynacji. Przekładając zindoktrynowany fanatyzm na kształtowanie modelu społeczeństwa, można doprowadzić do powstawania inicjatyw i różnego rodzaju grup lokalnych zapewniających właściwą egzystencję komunizmu, tym samym właściwe funkcjonowanie społeczeństwa i ewolucję idei samowystarczalności.

12 Ibidem, s. 143.

13 B.K. Martin, Under the Loving Care of the Fatherly Leader: North Korea and the Kim Dynasty, New York 2004, s. 383.

14 Kim Jong II, Socjalizm to nauka, [b.m.w] 2012, https://maopd.files.wordpress.com/ 2012/11/socjalizm-to-nauka-1994.pdf [dostęp: 23.09.2016], s. 28.

15 Ibidem, s. 27. 


\section{Konfucjańskie korzenie dżuczowskiego społeczeństwa}

Rozważając problematykę północnokoreańskiego społeczeństwa, należy również zwrócić uwagę na religijno-kulturowe fundamenty, na których została ona zbudowana. Konfucjanizm to system filozoficzno-religijny, panujący na Półwyspie Koreańskim od czasów starożytnych. System ten głęboko zakorzenił się w koreańskiej tradycji, kulturze, obyczajach i przyzwyczajeniach oraz ma wpływ na polityczne rozwiązania. W pewnym sensie konfucjanizm stanowi klucz do odpowiedniego zrozumienia specyfiki społeczeństwa w Korei Północnej. Ponadto, co ma znaczenie dla omawianego zagadnienia, ów system był inspiracją dla Kim Ir Sena, który dość obficie czerpał z nauk konfucjanizmu, zniekształcając jednakże pierwotną myśl konfucjańską ${ }^{16}$.

Główną zasadą zaczerpniętą z tradycji konfucjańskiej jest podział społeczeństwa na klasy. Społeczeństwo północnokoreańskie podzielone jest na trzy klasy, mianowicie klasę lojalną, chwiejną i wrogą. Ponadto, obecna jest w nim frakcyjność, skutkująca liczbą pięćdziesięciu jeden podklas ${ }^{17}$. Co ciekawe, rodzinę Kimów również obejmuje podział klasowy na tzw. miękki rdzeń i twardy rdzeń $^{18}$. Analizując kwestię podziału, można zauważyć, że ma on historyczne uzasadnienie. System klasowy istniał już w Królestwie Koryo, a w Królestwie Silla obecny był podział w monarchii ${ }^{19}$.

Kolejną zasadą wykorzystywaną przy tworzeniu dżuczowskiego społeczeństwa jest potraktowanie państwa, a w związku z tym całego narodu, jako zakładu wychowawczego z uczniami wymagającymi właściwej edukacji. W skutek tego, wódz stał się niedoścignionym wzorem do naśladowania, najlepszym nauczycielem, osobą wszechwiedzącą, znającą potrzeby wszystkich poszczególnych obywateli nowego państwa. W rezultacie, społeczeństwo zostało odseparowane od jakiejkolwiek własnej myśli i woli, ślepo wypełnia rozkazy swego najukochańszego Przywódcy.

16 W.J. Dziak, op. cit., s. 161.

17 P. French, North Korea. The Paranoid Peninsula. A Modern History, London-New York 2005, s. 42.

18 Zdaniem W.J. Dziaka, podziału dokonano po śmierci Kim Ir Sena, przy czym przynależność do któregokolwiek rdzenia zależy od stopnia pokrewieństwa członka rodziny z Kim Jong Ilem. Osoby z twardego rdzenia dopuszczone są do uczestnictwa w podejmowaniu decyzji i pozostawania w kręgu najwyższej elity, z której dokonuje się wyboru sukcesora. Podział na dwa rdzenie ma w dziejach Korei długą tradycję, w dodatku analogie do koreańskich dynastii są aż nadto zauważalne. W.J. Dziak, op. cit., s. 184-185.

19 Ibidem, s. 162-163. 
Nie bez znaczenia jest również kolejny element, jakim z pewnością jest przywiązanie do więzi rodzinnych. Wedle myśli konfucjańskiej osoba władcy stanowi patriarchę wielkiej rodziny, jaką niewątpliwie stanowią jego poddani. Także posłuszeństwo i oddanie władcy uważano za cnoty, ponadto, każdy miał przypisane określone role do spełnienia. Władca natomiast posiadał władzę absolutną, był pierwszorzędnym nauczycielem. Mógł karać za nieposłuszeństwo, które traktowano jako atak na harmonię i porządek wewnętrzny. Władca był obrońcą harmonii i jako taki stawał się przedmiotem kultu ${ }^{20}$. Mając powyższe na względzie, nietrudno zauważyć, że identyczna zależność ma miejsce w obrazie relacji między osobą wodza Korei Północnej a jego poddanymi, czyli społeczeństwem kraju.

\section{Społeczeństwo dżucze}

Należy przyznać, że społeczeństwo Korei Północnej jest wyjątkowe. Posiada wspólną ideę - dżucze, która łączy wszystkich obywateli kraju, jest oparte na kolektywizmie, jednakże pozbawione niezależności. W związku z powyższym warto podjąć próbę zdefiniowania go. A więc, dżuczowskie społeczeństwo jest przestrzenią działania instytucji państwowych, a konkretniej rzecz ujmując Partii Pracy Korei, grup lokalnych i jednostek działających na rzecz dobrego funkcjonowania komunizmu i głębszego utrwalania doktryny. Owa przestrzeń rozciąga się pomiędzy władcą, państwem, rodziną i mieszkańcami kraju. Zasadniczym elementem społeczeństwa jest samowystarczalność określona w ramach ideologii dżucze. To społeczeństwo wspólnotowe równych obywateli, odznaczające się kolektywnym myśleniem, odpowiedzialnością i sumieniem.

Jak można zauważyć, kimirsenowska koncepcja uformowała społeczeństwo w północnej części Półwyspu Koreańskiego. Aczkolwiek błędem jest nieuznawanie narodu Korei Północnej jako społeczeństwa obywatelskiego. Wyjaśniając, suwerenem jest naród, ale władzę w jego imieniu sprawuje partia rządząca, na czele z Przywódcą, władza działa na zasadach ustanowionych norm prawnych, państwo zapewnia prawny system gwarantujący ochronę praw wolności obywateli. Nadto, funkcjonują instytucje zapewniające przestrzeganie praw, a obywatele KRLD mają zagwarantowane prawo do uczestnictwa w życiu społeczno-politycznym.

Niezbędna jest tutaj pewna uwaga. Wedle A. Scobella, koncepcja dżucze postrzega społeczeństwo jako porozumienie wolnych i równych ludzi, którzy swoją wolność, jedność, odpowiedzialność, egzystencję i sumienie zawdzięczają

${ }_{20}$ Ibidem, s. 173-174. 
kolektywnej samowystarczalności. Powyższa odmiana consensusu opiera się na następujących zasadach:

- potrzeby ludzkie zaspokajane są przez podział pracy, centralnie sterowany rynek. Produkuje się pewne dobra, aby zaspokajać potrzeby, jednocześnie samemu jest się uzależnionym od wyników pracy innych osób. Przy czym należy pamiętać o idei samowystarczalności, która przejawia się tu następująco: jeżeli Koreańczycy nie są w stanie wyprodukować danej rzeczy w Korei z dostępnych na miejscu materiałów, to będą musieli poradzić sobie bez tej rzeczy. Dżucze jest przedstawicielem skromnej, acz prężnej gospodarki, co jest godne podziwu. Zakłada poświęcenie korzyści materialnych w imię wyższego celu, w imię wyższego dobra, co także nieodłącznie jednoczy obywateli;

- poszczególni obywatele społeczeństwa Korei Północnej są właścicielami i dysponentami pewnych zdolności oraz tego, co uzyskują przy wykorzystaniu swoich zdolności. Zatem należy uznać, że jednostki są równouprawnione, tzn. korzystają z równych szans i możliwości, aby się rozwinąć. Przy czym rozwój następuje tylko i wyłącznie w kolektywie. Warto poczynić tu komentarz: doktryna dżucze uznaje równość wszystkich ludzi w zakresie swych praw i obowiązków, ale wyklucza posiadanie przez wszystkich jednakowych umiejętności. Ideologia samowystarczalności to system, w którym każdy wykonuje pracę odpowiadającą jego zdolnościom i talentom ${ }^{21}$.

Wobec powyższego, nasuwa się następujący wniosek. Północnokoreańskie społeczeństwo realizuje wszystko to, czego wymaga od niego Wielki Wódz, a ustanowione prawo jest akceptowane przez obowiązujące normy moralne. Ponadto, zabrania się w nim jak najwięcej. Jednostki nie mogą postępować według swej woli i jednostkowo, nie posiadają również większej możliwości wyborów i rozwiązań, które zarówno dla indywidualnych obywateli, jak i dla społeczeństwa północnokoreańskiego byłyby najbardziej efektywne. Jednakże kładziony jest nacisk na rozwój kolektywny w myśl idei samowystarczalności. Tak pojmowane społeczeństwo zamyka możliwości dla swoich obywateli. Naród Korei Północnej cechuje brak różnorodności podmiotów i stosunków, które łączą te podmioty. Jedynie idea dżucze jest właściwą drogą postępowania, to ona ostatecznie decyduje o kierunkach rozwojowych i stanowi w pewnym sensie element spajający mieszkańców kraju.

Tego rodzaju normy uszczuplają ramy funkcjonowania północnokoreańskiego społeczeństwa. Jasper Becker podkreśla, że nie jest to równoznaczne z paraliżowaniem funkcjonowania Korei Północnej jako państwa czy ograniczaniem

${ }^{21}$ A. Scobell, Kim Jong Il and North Korea..., s. 6-30, 33-34. 
kraju w działaniu charakteryzującym się dobrą wolą. Aczkolwiek wola, czyli władztwo państwa, jest popierane przez wszystkich Koreańczyków z Północy, o czym nieustannie przypomina propaganda komunistycznego reżimu. Społeczeństwo KRLD posiada pewien wzór osobowy, do którego powinien aspirować każdy jego obywatel ${ }^{22}$. Wzory te pochodzą z koreańskiego doświadczenia historycznego i tradycji konfucjańskiej, np. postać wodza jako opiekuńczego ojca swojej rodziny, którą niewątpliwie jest cały naród koreański. Osoba Przywódcy sprawia, że każdy członek dżuczowskiego społeczeństwa to człowiek posiadający ambicje i aspiracje do perfekcjonistycznego doskonalenia zarówno siebie, jak i otaczającej go rzeczywistości. Trzeba jednak pamiętać, że byłoby wielką niestosownością stawianie się na równi z Wielkim Wodzem. Nadto, wzory te są niezmienne od momentu ustanowienia idei dżucze i stanowią wytyczne dla mieszkańców kraju. Kolejny niewątpliwy wzór to kolektyw, który w rzeczywistości Korei Północnej jest silnie zakorzeniony ${ }^{23}$.

Należy również wspomnieć, że społeczeństwo północnokoreańskie charakteryzuje się wewnętrzną dyscypliną, rozumianą jako zdolność do długodystansowego wysiłku w imię szerzenia idei $d \dot{u} u c z e$, co wymaga podporządkowania mniej ważnych rzeczy kwestiom niezwykle ważnym. Istotną cechą tej grupy społecznej jest również wola, a raczej przymus realizowania wyznaczonych zadañ ${ }^{24}$. Doktryna $d \dot{z} u c z e$ propaguje własne przekonania i interesy oraz broni ich, jest w pewnym sensie uczciwa intelektualnie. Dzięki niej społeczeństwo nie musi odczuwać strachu przed myślą, dlatego że koncepcja samowystarczalności skutecznie izoluje Koreańczyków z Północy od myślenia. Albowiem myśl bywa buntownicza, rewolucyjna, niszczycielska, anarchiczna, bezlitosna dla ustanowionego porządku społeczno-politycznego i obojętna wobec autorytetów.

\section{Funkcje i cechy dżuczowskiego społeczeństwa}

Ideologia dżucze odgrywa istotną rolę w procesie budowy społeczeństwa Korei Północnej. Analizując tę problematykę, można zauważyć, że idea spełnia następujące funkcje:

- funkcja edukacyjno-indoktrynacyjna - rozumiana jako forma oddziaływania, która wywiera znaczny wpływ na kształt świadomości i postaw północnokoreańskiego społeczeństwa;

22 J. Becker, Rogue Regime. Kim Jong Il and the Looming Threat of North Korea, New York 2005, s. 86-98.

23 W.J. Dziak, op. cit., s. 142.

24 S.A. Juetten, North Korea's Juche Ideology and the German Re-Unification Experience, Virginia 2008, s. 15-19. 
- funkcja integracyjna - odbierana jako oddziaływanie na egalitarne relacje pomiędzy podmiotami, które uczestniczą we wspólnej budowie komunizmu, rozwoju idei samowystarczalności i realizacji jej celów;

- funkcja mobilizacyjna - interpretowana jako zbiór merytorycznych norm i praktycznych instrumentów inspirujących naród koreański, władze państwowe oraz inne określone środowiska do aktywności w procesie formowania dżuczowskiego społeczeństwa;

- funkcja programowa - pojmowana jako bezpośrednie oddziaływanie na proces umacniania życia według koncepcji samowystarczalności oraz pośrednie relacje z możliwymi strategiami i programami umacniającymi idee $d \dot{z} u c z e^{25}$.

Każda $\mathrm{z}$ wymienionych funkcji jednocześnie zapewnia szansę i wyzwanie dla swoistych form aktywności, które są w zasięgu każdego Koreańczyka. Ponadto, sama doktryna stanowi impuls dla kreowania płaszczyzn wspólnotowego działania w ramach świadomego formowania społeczeństwa dżucze.

\section{Główne priorytety i rola dżucze w społeczeństwie}

Z diagnozy podstawowych komponentów społeczeństwa dżucze, z uwzględnieniem szans i zagrożeń jego rozwoju, wynika, że głównym składnikiem, a jednocześnie pierwszoplanowym determinantem rozwoju północnokoreańskiego społeczeństwa nie jest obywatel, ale właśnie idea dżucze. Obywatele są aktywni i świadomi w swoich działaniach, co może potwierdzać wysoki poziom podmiotowości społeczno-politycznej i ekonomicznej. Niemniej jednak wszelkie działania, wszelka świadomość jest wynikiem i przymusem doktryny dżucze. Wymiar tej podmiotowości najczęściej wyraża się w fanatycznym przestrzeganiu norm, organizowaniu życia i formowaniu lepszego społeczeństwa dżucze. Tylko ta idea jest w stanie wyartykułować potrzeby i interesy obywateli Korei Północnej. Dzięki koncepcji samowystarczalności naród koreański posiada zdolność wypełniania funkcji i realizowania zadań służących zaspokajaniu potrzeb społecznych oraz prowadzi działalność pożytku publicznego, co może realizować wspólnotowo z północnokoreańskimi instytucjami administracji publicznej. Powyższa forma aktywności wymaga właściwej edukacji w zakresie wiedzy Koreańczyka jako obywatela dżcze, kształtowania odpowiednich dżuczowsko-obywatelskich postaw, aktywizacji nie tylko na poziomie kolektywnym, ale i indywidualnym. Dopiero tacy aktywni, świadomi i ukierunkowani przez ideologię obywatele stanowią podstawowy komponent struktury

${ }_{25}$ Kim Sung Chull, North Korea under Kim Jong Il. From Consolidation to Systemic Dissonance, New York 2006, s. 165-192. 
społeczeństwa dżucze. Od stopnia ich zaangażowania zależy nie tylko dynamika rozwoju samowystarczalnego państwa, ale również samej doktryny, która będzie stanowiła bezpośrednią formę reprezentacji kolektywnego interesu.

Świadomi i aktywni obywatele dżucze permanentnie stanowią potencjał tworzący silną, zjednoczoną, spójną i aktywną wspólnotę kimirsenowskiej koncepcji. Urzeczywistniają najważniejsze normy i wartości dżuczowskiego ładu społecznego, który oparty jest na kolektywnej więzi społecznej. Społeczeństwo Korei Północnej jest zorganizowane w sposób kolektywny, stanowiąc determinantę ewolucji idei jako poszczególnej syntezy potencjału własnego, Partii Pracy Korei, instytucji państwowych i wzajemnych relacji zachodzących między nimi.

\section{Podsumowanie}

Zaproponowana przez Kim Ir Sena ideologia dżucze jest niezwykła. Warto się nią zainteresować z dwóch powodów. Po pierwsze, spośród wszystkich państw antykapitalistycznych, Korea Północna nie została zniszczona w wyniku działań odśrodkowych lub wojennych, jak miało to miejsce w przypadku pozostałych krajów totalitarnych. Po drugie, można stwierdzić, że Korea Północna jest, ze wszystkich państw wrogim Stanom Zjednoczonym, największym antagonistą i to przeciwko niej kierowane są najsilniejsze ataki amerykańskiej propagandy. Pomimo to, reżim koreański z ideologią dżucze na czele jest stabilny.

Idea społeczeństwa dżucze, która posiada zarówno zwolenników, jak i przeciwników, może być uznana za kontrowersyjną. Kimirsenowska doktryna silnie oddziałuje nie tylko na aspekt polityczno-ekonomiczny, ale również na sferę społeczno-kulturową. Takie podejście należy uznać za ogromne zagrożenie dla idei narodu północnokoreańskiego. Niemniej jednak wypada podkreślić, że społeczeństwo dżucze zostało ukształtowane na solidnych fundamentach, jakimi niewątpliwie są konfucjańska tradycja, respektowana kultura, samowystarczalność, wolność czy kolektywny rozwój.

Opisując naród Korei Północnej, trzeba zaznaczyć, że charakteryzuje się on kolektywną egzystencją. Nie ma w nim miejsca na indywidualny rozwój jednostek, a północnokoreańskie społeczeństwo nacechowane jest brakiem niezależności. Przede wszystkim łatwo zauważalna jest nieobecność własnego myślenia. Istnieje tylko jedna, wszechobecna myśl Wielkiego Wodza, którą każdy powinien wypełniać bez zakwestionowania. Jednostki, aby się rozwijać, muszą prowadzić kolektywne życie społeczno-polityczne, wszystko na rzecz właściwego rozwoju idei samowystarczalności i istnienia dżuczowskiego ładu społecznego.

W Korei Północnej istnieje wspomniana wcześniej bogata i wartościowa tradycja konfucjańska. Trzeba zaznaczyć, że formułując swoją koncepcję, 
Kim Ir Sen powoływał się w niektórych aspektach na istniejący w Korei od najdawniejszych czasów system filozoficzno-religijny. W związku z powyższym, konfucjanizm i doktryna dżucze odegrały znaczący wpływ na funkcjonowanie społeczeństwa na północy Półwyspu Koreańskiego. Korea Północna o dżuczowskiej orientacji społeczeństwa może posłużyć jako wyznacznik godnego życia, gdzie powszechnie akceptowane są uniwersalne i nadrzędne wartości koncepcji Najukochańszego Przywódcy.

Niemniej jednak kimirsenowska koncepcja pełni znaczącą funkcję kształtującą i jednoczącą naród Korei Północnej. Ponieważ dzięki tej ideologii każdy mieszkaniec państwa może być w pełni ukształtowany, posiada możliwość do aktywności społeczno-politycznej. Idea dżucze jest inspiracją do tworzenia wspólnotowego działania, integruje i mobilizuje północnokoreańskie społeczeństwo. Doktryna kształtuje i zakorzenia w obywatelach właściwe postawy, nacechowane myśleniem $w$ ramach idei. Wręcz idzie krok do przodu, oznajmiając, że od każdego obywatela w państwie zależy sukces rewolucji. Z tego też powodu każdemu Koreańczykowi, który stał się pełnoletni wydawana jest broń i oczekuje się od niego walki za ojczyznę. Nawet jeśli rząd i armia północnokoreańska poniosłyby klęskę, ludzie mają walczyć do końca, nawet gdy nie będzie jakichkolwiek struktur dowodzenia, mają prowadzić walkę do ostatniej kropli krwi.

Wydaje się, że społeczeństwo Korei Północnej jest zatopione w ideologicznym absolucie. Tym samym, z punktu widzenia Kim Ir Sena, może czuć się wolne, spełnione i bliskie ideału.

\section{Bibliografia}

Becker J., Rogue Regime. Kim Jong Il and the Looming Threat of North Korea, New York 2005.

Cornell E., North Korea under Communism: Report of an Envoy to Paradise, London 2002.

Dziak W.J., Korea Północna. U źródeł rodzinnej sukcesji, Warszawa 2009.

French P., North Korea. The Paranoid Peninsula. A Modern History, LondonNew York 2005.

Hale C., Multifunctional Juche: A Study of the Changing Dynamic between Juche and the State Constitution in North Korea, „Korean Journal” 2002, no. 3, s. 283-308.

Juetten S.A., North Korea's Juche Ideology and the German Re-Unification Experience, Virginia 2008.

Kim Ir Sen, O rewolucjonizowaniu całego społeczeństwa i przeobrażaniu jego na obraz klasy robotniczej, Phenian 1982. 
Kim Jong Il, Socjalizm to nauka, [b.m.w] 2012, https://maopd.files.wordpress. com/2012/11/socjalizm-to-nauka-1994.pdf [dostęp: 23.09.2016].

Kim Jong Il, Szkalowanie socjalizmu jest niedopuszczalne, Warszawa 1994.

Kim Sung Chull, North Korea under Kim Jong Il. From Consolidation to Systemic Dissonance, New York 2006.

Martin B.K., Under the Loving Care of the Fatherly Leader: North Korea and the Kim Dynasty, New York 2004.

Scobell A., Kim Jong Il and North Korea: The Leader and the System, Morrisville 2013.

\begin{abstract}
The Juche ideology, despite political and economic aspects, has influenced socio-cultural aspect in North Korea. Kim Il Sung's doctrine is an important factor that strongly unites state's inhabitants. North Korean society, which can be called juche society, was formed on solid foundations that have historical and doctrinal conditions. Furthermore, juche' function is to mobilize and integrate North Korean society. It is also an inspiration to community activity. It provides entity's progress but under collective. Additionally, North Korean society shows thinking due to juche ideology.

The purpose of this publication is to show juche as an important factor that influences and unites North Korean society.
\end{abstract}

Keywords: juche, juche society, Confucianism 